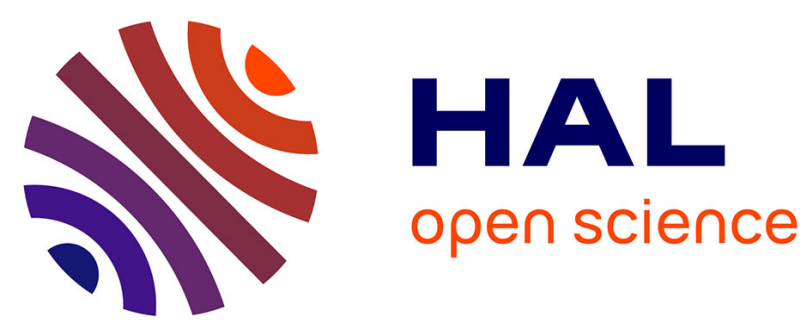

\title{
The strength of biogenic sand reefs: Visco-elastic behaviour of cement secreted by the tube building polychaete Sabellaria alveolata, Linnaeus, 1767
}

Jean-Benoit Le Cam, Jérôme Fournier, Samuel Etienne, Jérôme Couden

\section{To cite this version:}

Jean-Benoit Le Cam, Jérôme Fournier, Samuel Etienne, Jérôme Couden. The strength of biogenic sand reefs: Visco-elastic behaviour of cement secreted by the tube building polychaete Sabellaria alveolata, Linnaeus, 1767. Estuarine, Coastal and Shelf Science, 2011, 91 (2), pp.333-339. 10.1016/j.ecss.2010.10.036 . hal-00565092

\section{HAL Id: hal-00565092 https://hal.science/hal-00565092}

Submitted on 22 Jul 2020

HAL is a multi-disciplinary open access archive for the deposit and dissemination of scientific research documents, whether they are published or not. The documents may come from teaching and research institutions in France or abroad, or from public or private research centers.
L'archive ouverte pluridisciplinaire HAL, est destinée au dépôt et à la diffusion de documents scientifiques de niveau recherche, publiés ou non, émanant des établissements d'enseignement et de recherche français ou étrangers, des laboratoires publics ou privés. 


\section{The strength of biogenic sand reefs: visco-elastic behaviour of cement secreted by the tube building polychaete Sabellaria alveolata, Linnaeus, 1767.}

Jean-Benoît Le Cam ${ }^{1}$, Jérôme Fournier ${ }^{2}$, Samuel Etienne ${ }^{3,4}$, Jérôme Couden ${ }^{1}$

${ }^{1}$ Clermont Université, Institut Français de Mécanique Avancée, CNRS-EA 3867-FR TIMS 2856, Laboratoire de Mécanique et Ingénieries, BP 265, 63175 Aubière cedex, France

${ }^{2}$ CNRS, UMR 7208 BOREA, Muséum National d'Histoire Naturelle 61, rue Buffon, CP53, 75231 Paris cedex 05, France

${ }^{3}$ Université de la Polynésie française, BP 6570, 98702 Faa'a, Tahiti, French Polynesia

${ }^{4}$ CNRS, UMR 6042 GEOLAB, 4 rue Ledru, 63038 Clermont-Ferrand cedex 1, France

Corresponding author: Jean-Benoît Le Cam, Institut Français de Mécanique Avancée, BP 265, 63175 Aubière cedex, France. Tel. (+33).4.73.28.81.20 ; Fax. (+33).4.73.28.81.00 ; email. jean-benoit.lecam@ifma.fr

\section{Abstract}

Mechanical properties of the biomineralised cement from tube-building marine worms are poorly known. Secreted from an organ connected to the polychaetes specialised glands, the cement glues sand grains and calcareous shell fragments of a given size and, on a larger scale, and ensures the resistance of the reef to waves. In this study, three kinds of mechanical tests were performed with worm tubes to establish the nature of the cement behaviour. Results obtained show that cement behaves like a visco-elastic material. This property allows the tubes to dissipate the mechanical energy from the waves to which they are subject and to reduce the mechanical stress transmitted inside the tubes to the polychaetes. Comparison of "fresh" and "dry" cements highlights that the visco-elastic behaviour of the cement is maintained after five years. The viscosity of the cement is therefore not related to moisture but to its chemical composition. More generally, these results offer a better understanding of the role of cement on worm reefs strength and their persistence in the geological record.

Keywords 
Biogeomorphology; Biogenic reef; Sabellaria alveolata; Mechanical behaviour; Viscoelasticity

\section{Introduction}

Some marine annelids are known to build and to maintain massive sandy reefs which can cover several kilometres in length (Caline et al., 1988). The family Sabellariidae aggregates several species of reef building polychaetes which are present along all coastlines, except the Arctic. The sabellariid polychaete Sabellaria alveolata Linnaeus, 1767 forms large intertidal colonies at the north-western coasts of Europe, especially in the Bay of Mont-Saint-Michel (France) which hosts the greatest European worm-reef structures (Dubois et al., 2002; Godet et al., 2009; Noernberg et al., 2010). These annelid reefs are known to trap carbonate-rich sediments and to actively control the texture and the distribution of intertidal sediments (Godet et al., 2008; Kirtley and Tanner, 1968; Toupoint et al., 2008). The single tube of each individual is made from bioclastic sand of a given size and shape, gathered in the water column when the reef is submerged at high tide. The rigidity of the tube is acquired at low energetic cost because the bioclastic grains have the shape of small tiles and thus, a large surface area per unit of mass. The tubes constructed are joined together with a bio-mineralised cement which is produced by specialised glands, located in the thorax of the worm. The cement of sabellariid species such as Phragmatopoma spp. and S. alveolata consists of several protein substances such as glycine, serine and alanine (Waite et al., 1992; Zhao et al., 2005), and significant levels of phosphorus, calcium and magnesium (Gruet et al., 1987; Fournier et al., 2010). The matrix of the cement is pitted with spheroidal depressions and is shaped like a microporous foam (Stewart et al., 2004; Flammang and Lambert, 2008). Zhao et al. (2005) and Stevens et al. (2007) have demonstrated that the difference in $\mathrm{pH}$ between the secretory glands and seawater might explain the drying out reaction mechanism involving an initial rapid $\left(30 \mathrm{~s}^{-1}\right)$ change in the nature of the bonding of divalent cations with the protein Pc 3 , and secondly a reaction characterized by a slower hardening of the cement. Earlier studies showed that the stability of the cement in S. alveolata tubes is achieved by internal quinone tanning (Gruet et al., 1987), but calcium or magnesium depletion can affect the structural and mechanical properties of the cement by lowering pull-out forces and tube compressive strength (Sun et al., 2007). Paradoxically at first sight, several studies have also underlined the fragility of the reefs built by these worms but, at the same time, their strength to withstand the 
hydrodynamic pressure (i.e. wave energy dissipation) over long periods of time (Kirtley and Tanner, 1968; Caline et al., 1988; Main and Nelson, 1988). In the Bay of Mont-Saint-Michel, the amplitude of the swell only exceeds $2 \mathrm{~m}$ about ten days a year with a maximum of $3.5 \mathrm{~m}$; $50 \%$ of the record reveal that the amplitude remains under $0.5 \mathrm{~m}$ with a period between 7 and $11 \mathrm{~s}^{-1}$. Occasionally, lapping waves, which are caused by winds stronger than $12.5 \mathrm{~m} . \mathrm{s}^{-1}$, are superimposed on the north-west swells (Caline et al., 1988). The aim of this paper is to study the mechanical properties of the biogenic cement in order to understand its role in the resistance of individual tubes of $S$. alveolata to physical pressure, a questioning that has been performed on other species of reef-building worm (e.g. Lanice conchilega: Callaway et al., 2010). This study is the first step towards the characterisation of the resistance of reefs to breaking waves, especially in the context of global change with increasing wave energy at coasts (Allan and Komar, 2000; Goldenberg et al., 2001). Three different mechanical tests have been used to distinguish the behaviour of tubes when some compressive constraints are applied. The first test intends to establish the mechanism of failure of the tube submitted to a compression loading. The second one was used to define the nature of the mechanical behaviour of the cement. The last one aims to compare the nature of the mechanical behaviour of fresh and old cements, and more particularly their viscosity.

\section{Experimental set-up}

\subsection{Materials and sample geometries}

Several blocks of tubes of Sabellaria alveolata were collected in 2010 in the main reef (ca $150 \mathrm{ha}$ ) located in the central part of the bay of Mont-Saint-Michel and stored in plastic bags (Figure 1). All collected tubes were constructed by adult worms. The higher parts of the tubes were carefully and individually separated from the block with scalpel in the laboratory. The top of the tubes was selected as this part of the tube is the most recently built. Replicates were stored for both mechanical tests and grain-size analysis. For grain-size analysis of each of the samples, segments of tubes were washed carefully with distilled water and following decanting during $48 \mathrm{~h}$. Sediments were then dried at $60^{\circ} \mathrm{C}$ for $24 \mathrm{~h}$ and were then sieved through AFNOR standard sieves (meshes of 2.5, 2, 1.6, 1.25, 1, 0.8, 0.63, 0.50, 0.40, 0.315, $0.25,0.20,0.16,0.125,0.100 \mathrm{~mm}, 80,63,50,40$ and $<40 \mu \mathrm{m})$. Each size fraction was weighed and the associated results expressed as percentages of the total sample weight. Sedimentary parameters were determined by performing grain-size analysis on raw data 
through the Gradistats v.4.1. Program (Blott and Pye, 2001) based on the methods of moments using the Folk and Ward (1957) classification. Three types of samples, named "A", "B" and "C" were prepared for mechanical tests. "A" samples were collected on the backreef, an area sheltered from the incoming swells (azimuth: $185^{\circ}$ ). In contrast, "B" and "C" samples were collected on the fore-reef, where worm tubes are directly exposed to swells and waves (azimuth: $20^{\circ}$ and $30^{\circ}$ respectively). "A" samples (20 mm long) were tested 3 days after their collection on the field. These fresh samples remained wet during the storage period. Preliminary compressive tests until fracture were conducted with respect to the natural sample geometry: it should be noted that sample axis is not necessarily strictly linear. For this reason, the length of " $\mathrm{B}$ " samples was reduced by cutting to $10 \mathrm{~mm}$ to minimize the geometrical effect on the mechanical response. This sample geometry was used to performed cyclic mechanical tests. Finally, "C" samples, collected in 2004 in the same location and stored in a dry storage room, were used to compare the mechanical behaviour of an "old" and dried-up cement with a fresh one. The length of the tube used for this last test was around $20 \mathrm{~mm}$ as these tubes were strictly linear.

\subsection{Mechanical tests}

The mechanical tests were performed at $23^{\circ} \mathrm{C}$ room temperature and $34 \%$ hygrometry using a $50 \mathrm{~N}$ Instron 5543 testing machine. As shown in Figure 2, tubes are placed on the plate surface of the fixed grip. Then, the moving grip is put into contact with the tube and is moved toward the fixed grip in order to generate a radial compression loading on the tube. The frequency of acquisition allows us to obtain one measurement of the grip displacement and applied force every $100 \mathrm{~ms}$. Three kinds of compressive tests were carried out. The first one with five A-type samples aims to characterize the response until fracture in terms of displacement-force relationship. This test until fracture is classically envisaged to determine the stiffness and the failure mode of materials and structures (Sharpe, 2008). The second test deals with the nature of the cement behaviour and tries to answer some important questions: is the cement behaviour elastic? Is there a viscous contribution to the mechanical response? Is there any mechanical irreversibility? To investigate these questions, mechanical cycles are 
performed with B-type samples. They consist in performing three cycles at three increasing displacement levels, in this case $-0.2,-0.4$ and $-0.6 \mathrm{~mm}$. The third test was performed after obtaining the results of the second test and is dedicated to the stress relaxation, i.e. the effect of the apparent viscosity at the macroscopic scale, on the mechanical response of B-type and C-type samples. This test was chosen to compare the nature of the behaviour of fresh (B-type samples) and 5 year-old (C-type samples) cements.

2 Results

\subsection{Grain-size analysis of the tubes}

Geometry and conservation state of tube samples are summarized in Table 1. Average values of the external and internal diameters of the tubes were computed with $\mathrm{R}$ language and environment ( $\mathrm{R}$ Development Core Team, 2009). Beforehand, data normality has been verified with a Shapiro-Wilk test. Linear regression shows that the external and internal diameters of the tubes seem to be strongly dependant for all types of samples. We have checked this positive relation for the tubes of samples $\mathrm{A}\left(\mathrm{R}^{2}=0.9468, F_{1,16}=303.8 ; p<\right.$ $0.001)$, samples $\mathrm{B}\left(\mathrm{R}^{2}=0.8168, F_{1,16}=76.8 ; p<0.001\right)$ and samples $\mathrm{C}\left(\mathrm{R}^{2}=0.8922, F_{1,18}=\right.$ 158.2; $p<0.001)$. Differences between samples in diameter are explained mainly by the age of the worms and the orientation of the reef blocks in relation to the waves. Table 2 gives the result of grain-size parameters of the groups of tubes for the three samples used for mechanical tests. Samples B are composed of clasts slightly coarser (mean $360.39 \mu \mathrm{m}$ ) than those of samples A (mean $347.73 \mu \mathrm{m}$ ). Clasts of samples C are even coarser (mean 465.15 $\mu \mathrm{m})$ but the mode is identical $(565 \mu \mathrm{m})$ to the other two. The percentage of $\mathrm{CaCO}_{3}$ (i.e. bioclasts) is comparable, $76.2 \%$ for samples A, $78.6 \%$ for samples B and $82.3 \%$ for samples C.

\subsection{Compression until failure}

The tests were carried out with A-type samples. The mechanical responses obtained are plotted in a displacement - force diagram (Figure 1). As the average section of the samples slightly differs from one to another (see Table 1), the force is normalized by the maximum force obtained during the test for each sample. Results obtained shows that samples exhibit 
similar mechanical response. The responses being very close, only two curves are plotted in the displacement-force diagram in Figure 2. The great repeatability of the tube response obtained with the compression test allows us to analyse more precisely the typical response curve in relation with the evolution of the sample structure during the test. The typical response of the samples can be divided in 7 steps (figure 3), each one corresponding to a singular phase of deformation and/or failure observed during the tests:

Step 1: the compressive force slightly increases. The force distribution is not homogeneous along the sample due to both the variation in the external diameter and the non-linearity of the axis. The parts of the tube with the largest diameter are therefore the most stressed;

Step 2: sample split into several segments. Even if the displacement increases continuously, this mechanism occurs under constant force and consequently the segments of the tube realign parallel to the surface of the grips;

Step 3: the compressive force is now applied on the largest segments of the sample;

Step 4: the outer segments do not resist the force any more and fail;

Step 5: as a consequence, the lower diameter parts are now loaded;

Step 6: the same mechanism of failure takes place;

Step 7: once the last segments failed, the force returns close to zero. The fact that the force level increases with the displacement is explained by the particle compaction.

\subsection{Cyclic compression}

Figure 4 shows the response of B-type samples obtained under three cycles at three different increasing displacements. The aim of this test is to study the behaviour of the cement using the global response of the samples. This kind of tests allows us to identify viscosity in the mechanical response and to study the damage process. Examining the first level of displacement applied, during the first loading the force reaches a value from which the displacement increases without force increasing. As previously explained, this could be due to the local failure of the sample. From $-0.2 \mathrm{~mm}$ on, the displacement comes back to zero but the corresponding part of the curve shows that the force returns quickly to zero, just after the displacement begins to decrease. This mechanical cycle exhibits a hysteresis loop that is mainly due to the dissipation of the mechanical energy by successive local failures. The two next cycles are also interesting because no local failures are detected from the curve but the loading and unloading paths are different. As the fourth cycle is performed at a higher level of 
displacement, the force increases until reaching a maximum value and the same phenomena as for the first cycle are observed. It should be noted that local failure occurs at a higher force level than cycle 1.

\subsection{Relaxation test under compression}

Figures 5 and 6 present the results obtained for B-type and C-type samples, respectively. We recall here that the diameter of the tubes, the size and shape of particles agglomerated using cement are different. This explains the difference in the force level between the two samples. However, the mechanical response of the cement is significantly affected neither by the change in size of the tube nor the change in size and shape of particles. The test consists in applying consecutive displacements of $-0.2,-0.4$ and $-0.6 \mathrm{~mm}$ and to measure the force variation during $60 \mathrm{~s}$. The displacement level applied is defined during preliminary tests in order to prevent local failure of the tube. Figure 5 shows representative responses of B-type samples. A small stress relaxation is observed at $-0.2 \mathrm{~mm}$ and the force rapidly stabilizes. At $0.4 \mathrm{~mm}$, the stress strongly relaxes and the force does not stabilize after $60 \mathrm{~s}$. When examining the representative response of the C-type samples (Figure 6), a similar phenomenon is observed: stress relaxation is observed during each stop and the force reached at $-0.6 \mathrm{~mm}$ is not significantly higher than that reached at $-0.4 \mathrm{~mm}$.

\section{Discussion}

The initial motivation of this study was to characterize the mechanical properties of biogenic cement and to understand its role in the resistance of individual worm tubes to physical loading conditions. The first tests performed (compression until fracture) have allowed the conceptualisation of the mechanical response of the tube through a seven steps model. Even though this kind of test has revealed the mechanism of failure of the tubes under compression loading, only two phases ( 3 and 5) correspond to the requested uniform and longitudinal compression of segments of the samples. Therefore, it seems difficult to use the mechanical response obtained to define the true nature of the cement behaviour. Thus, once the tests performed, some questions remain unanswered: if the displacement of the moving grip is stopped before sample failure and returned to zero, are the loading and unloading paths the same? In other words is the behaviour of the cement elastic, elasto-plastic, visco-elastic or 
visco-elasto-plastic? Is it possible to distinguish the contribution of the structure and that of the cement to the mechanical response?

As a first answer, the cyclic tests have revealed a hysteresis loop, due to the mechanical response of the cement. In fact, the cement behaves like a visco-elastic material and is able to dissipate partially of the mechanical energy brought to it. Moreover, the fact that these two hysteresis loops (cycles 2 and 3, Figure 4) are superimposed seems to indicate that these mechanical cycles do not generate irreversibility and that the cement behaviour is stabilized. This seems to indicate that mechanical cycles applied at a given level confer to the cement a higher resistance to local failures. Back to a natural context, this indicates that the cement could accommodate a certain increase in the mechanical energy brought by breaking waves. For the third level of displacement, the force does not exceed the maximum value obtained during the last cycles. This could be explained by the fact that the tube is not able to resist to a higher force level anymore. To conclude on this second test, the cement seems to behave as a visco-elastic material and its ability to dissipate the mechanical energy brought to it explains why samples can reduce the effect of loading on the polychaetes.

Finally, the comparison between both old and dried tubes and fresh tubes shows that a large difference in the force value is observed between the two first levels of displacement during the relaxation test. Yet, the third level of constraints applied induces a level of the force and a stress relaxation similar to the second level of displacement. This seems to indicate that the cement is suppler (at a given force) after a first relaxation phase. The fact that such a relaxation phenomenon is clearly observed in the response of the C-type samples shows that the tubes are still able to dissipate energy five years after sampling. With regards to these results, we assume that the conservation of the mechanical properties of the cement, i.e. its visco-elasticity, could explain the astonishing resistance of the tubes, and the reef $v i s-\grave{a}$-vis the hydrodynamic constraints. The sustainment of mechanical properties might explain the ability of sand-castle reefs to be preserved as fossils in geological records (Fisher et al., 1989; Garcin and Vachard, 1987; Eckdal and Lewis, 1993). Fossilization of these bioconstructions suggests that tubes are able to keep their shape and strength for prolonged periods of time.

Conclusion 
This study specifies the mechanical characterization of cements using three compression tests. The first one consists in compressing samples until their rupture. The second one imposes three cycles at three increased levels of compression. The third one corresponds to a test of relaxation on three increased levels of compression. The main result obtained highlights the visco-elastic behaviour of cement of Sabellaria alveolata. This behaviour enables the tube to dissipate the mechanical energy brought by breaking waves. Consequently, only part of this mechanical energy is transferred to the worm. The cement seems therefore to take part directly in the protection of the worms and the reef by dissipating the energy of the waves.

The global climatic change and the predicted rise in sea level present a potential direct impact on the worm-reefs: an increase in wave energy levels which induces a higher level of mechanical loading. This study has shown that tubes of Sabellaria alveolata are able to undergo an increase in the mechanical loading without any structural damage. The threshold of resistance of the reefs facing the increase in wave energy remains to be quantified with in situ experiments.

\section{Acknowledgements}

This work has been funded by University Blaise Pascal, Clermont-Ferrand (BQR 2007). We especially thank MSc Amelia Curd (MNHN) for English editing. We also greatly thank the two anonymous reviewers for comments and improvement of the manuscript.

\section{References}

Allan, J., Komar, P., 2000. Are ocean wave heights increasing in the eastern north Pacific? EOS, Transactions, American Geophysical Union 81, 561-567.

Blott, S., Pye, K., 2001. Gradistat: grain size distribution and statistics package for the analysis of unconsolidated sediment. Earth, Surface Processes and Landforms 26, 1237-1248.

Caline, B., Gruet, Y., Legendre, C., Le Rhun, J., L'Homer, A., Mathieu, R., Zbinden, R., 1988. Les récifs à Annélides (Hermelles) en Baie du Mont-Saint-Michel. Écologie, géomorphologie, sédimentologie, implications géologiques. Documents du Bureau de Recherches Géologiques et Minières 156, Orléans. 
Callaway, R., Desroy, N., Dubois, S., Fournier, J., Frost, M., Godet, L., Hendrick, V., Rabaut, M., 2010. Ephemeral bio-engineers or reef builders: how stable are aggregations of the tube worm Lanice conchilega (Pallas, 1766)? Integrative and Comparative Biology 50(2), $237-\S 250$.

Dubois, S., Retière, C., Olivier, F., 2002. Biodiversity associated with Sabellaria alveolata (Polychaeta: Sabellariidae) reefs: effects of human disturbances. Journal of the Marine Biological Association of the United Kingdom 82, 817-826.

Eckdal, A.A., Lewis, D.W., 1993. Sabellariid reefs in Ruby Bay, New Zealand: a modern analogue of Skolithos "Piperock" that is not produced by burrowing activity. Palaios 8(6), 614-620.

Fisher, R., Galli, O.C., Reitner, J., 1989. Skeletal structure, growth, and palaecology of the patch reef-building polychaete worm Diplochaetes mexicanus Wilson, 1986 from the Oligocene of Baja California (Mexico). Geobios 22, 761-775.

Flammang, P., Lambert, A., 2008. Cement ultrastructure and adhesive glands morphology in the tube-dwelling polychaete Sabellaria alveolata. Journal of Morphology 269, 479-11479.

Folk, R.L., Ward, W.C., 1957. Brazos River bar: a study in the significance of grain size parameters. Journal of Sedimentary Petrology 27, 3-26.

Fournier J., Etienne S., Le Cam J.-B. 2010. Inter- and intraspecific variability in the chemical composition of the mineral phase of cements from several tube-building polychaetes. Geobios 43, 191-200.

Garcin, M., Vachard, D., 1987. Découverte d'hermelles fossiles dans le Messinien de San Miguel de Salinas (Annélides du Miocène supérieur du Sud-Est de l'Espagne). Geobios 20, 407-414. 
Godet, L., Fournier, J., Toupoint, N., Olivier, F., 2009. Mapping and monitoring intertidal benthic habitats: a review of techniques and proposal of a new visual methodology for the European coasts. Progress in Physical Geography 33(3), 378\$-402.

Godet, L., Toupoint, N., Olivier, F., Fournier, J., Retière, C., 2008. Considering the functional value of common marine species as a conservation stake. The case of the sandmason worm Lanice conchilega (Annelid polychaeta, Pallas 1766) beds. Ambio: A Journal of the Human Environment 37(5), 347-§355.

Goldenberg, S.B., Landsea, C.W., Mestas-Nuñez, A.M., Gray, W.M., 2001. The recent increase in Atlantic hurricane activity: causes and implications. Science 293, 1474-1479.

Gruet, Y., Vovelle, J., Grasset, M., 1987. Biomineral components of tube cement of Sabellaria alveolata (L.) (Annelida, Polychaeta). Canadian Journal of Zoology 65, 837-842.

Jensen, R.A., Morse, D.E., 1988. The bioadhesive of Phragmatopoma californica tubes - a silk-like cement containing L-Dopa. Journal of Comparative Physiology B Biochemical, Systemic and Environmental Physiology 158, 317-324.

Kirtley, D.W., Tanner, W.F., 1968. Sabellariid worms: builders of a major reef type. Journal of Sedimentary Petrology 38, 73-78.

Main, M.B., Nelson, W.G., 1988. Sedimentary characteristics of Sabellariid worm reefs (Phragmatopoma lapidosa Kinberg). Estuarine, Coastal and Shelf Science 26, 105-109.

Noernberg, M., Fournier, J., Dubois, S., Populus, J., 2010. Using airborne laser altimetry to estimate Sabellaria alveolata (L.) (Polychaeta: Sabellariidae) reefs volume in tidal flat environment. Estuarine, Coastal and Shelf Science (in press).

R Development Core Team, 2009. R: a language and environment for statistical computing. R Foundation for Statistical Computing, Vienna, Austria. ISBN 3-900051-07-0. Available from www.R-project.org. 
Shao, H., Bachus, K.N., Stewart, R.J., 2009. A water-borne adhesive modelled after the sandcastle glue of $P$. californica. Macromolecular Bioscience 9, 464-471.

Sharpe, W.N., 2008. Handbook of experimental solid mechanics, Springer Science + Bussiness Media LLC New York.

Stevens, M.J., Steren, R.E., Hlady, V., Stewart, R.J., 2007. Multiscale structure of the underwater adhesive of Phragmatopoma californica: a nanostructured latex with a steep microporosity gradient. Langmuir 23, 5045-5049.

Stewart, R.J.,Weaver, J.C., Morse, D.E.,Waite, J.H., 2004. The tube cement of Phragmatopoma californica: a solid foam. Journal of Experimental Biology 207, 4727-4734.

Sun, C., Fanter, G.E., Adams, J., Hansma, P.K., Waite, J.H., 2007. The role of calcium and magnesium in the concrete tubes of the sandcastle worm. Journal of Experimental Biology 210, 1481-1488.

Toupoint, N., Godet, L., Fournier, J., Retière, C., Olivier, F., 2008. Does Manila Clam cultivation affect habitats of the engineer species Lanice conchilega (Pallas, 1766)? Marine Pollution Bulletin 56(8), 1429-§1438.

Waite, J.H., 1987. Nature's underwater adhesive specialist. International Journal of Adhesion and Adhesives 7, 9-14.

Waite, J.H., Jensen, R.A., Morse, D.E., 1992. Cement precursor proteins of the reef-building polychaete Phragmatopoma californica (Fewkes). Biochemistry (American Chemical Society) $31,5733-5738$.

Zhao, H., Sun, C., Stewart, R.J.,Waite, J.H., 2005. Cement proteins of the tube building Polychaete Phragmatopoma californica. Journal of Biological Chemistry 280, 42938-42944.

Table captions 
Table 1. Sabellaria alveolata tube characteristics, Saint-Anne reef, Bay of Mont-SaintMichel, France

Table 2. Grain-size parameters of tubes used for mechanical tests (geometric methods of moments)

Figure captions

Figure1. Location of the study area (Mont-Saint-Michel Bay, France) and location of the sampling area (Reef of 'Sainte-Anne') and samples A, B and C.

Figure 2. Compression test until sample fracture

Figure 3. Conceptual model of the variation in the sample structure during the compression test until fracture

Figure 4. Cyclic compression test. Three cycles are performed at three increasing compression levels

Figure 5. Relaxation test under compression (B-type samples)

Figure 6. Relaxation test under compression (C-type samples) 